(C) 1990 ISIJ

IIIIIIIIIIIIIIIIII!

論 文

"IIIIIIIIIIIIIII!

\title{
炭素の結晶・非結晶の割合を考慮した コークスガス化反応の速度解析
}

\author{
柏 谷 悦 章*.石 井邦 宜 ${ }^{* 2}$
}

\author{
Kinetic Analysis of Coke Gasification Based on Non-crystal/Crystal \\ Ratio of Carbon
}

Yoshiaki KASHIWAYA and Kuniyoshi ISHII

\begin{abstract}
Synopsis :
Gasification of metallurgical coke was studied at $1000,1200,1400^{\circ} \mathrm{C}$ with $\mathrm{Ar}-\mathrm{CO}-\mathrm{CO}_{2}$ mixtures. Reaction of coke in blast furnace is dominant from about $900^{\circ} \mathrm{C}$. And at the same time, growth of graphite crystal (crystallite) in coke begins to occur from that temperature.

In present paper, two types of carbon crystal were classified by means of X-ray diffraction. One is crystallite that contribute to $\mathrm{X}$-ray diffraction, another is noncrystalline carbon that contribute only to background intensity. In this study, reaction model that the two kinds of carbon have different reactivity and react simultaneously and independently, was developed and kinetic analysis was performed.

Following results were obtained.

(1) $L c$ increases as function of temperature and there is no influence of reaction. (2) $L a$ increases as function of temperature in Ar atmosphere. But in existence of reaction, the size of $L a$ is so smaller. From this result, it was considered that the gasification reaction proceeds such as mode of decreasing $L a$. And reaction mechanism combining to characteristic of crystallographic structure is proposed.

Key words : metallurgical coke; gasification; kinetic analysis; crystalline size of carbon; reaction mechanism; X-ray diffraction.
\end{abstract}

1. 緒

\section{言}

高炉内コークスの挙動は反応および強度の両面から操 業に多大の影響を与えるため, 多数の研究がなされてい る. 反応性に関係したものに限っても, 速度論的な研

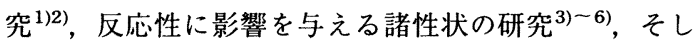
て高炉内における性状変化 ${ }^{3) 7)}$ など, 報告が多い. しか しながら, コークスの性状は, 原料炭の特性と製造履歴 によって複雑に変化し, 速度論的取扱いにおいても, 得 られる速度定数は試料ごとに異なるため, 普遍的な意味 を持たない.

高炉内において，コークスのソリューションロス反応 (ガス化反応) は約 $900^{\circ} \mathrm{C}$ から顕著になるが, 同時にこ の温度から, コークス中の黒鉛結晶（結晶子, Crystallite とよぶ) の成長も始まる. 炭素材料の反応性は, そ の黒鉛化度とともに低下し, 逆に無定形炭素に近づくほ
ど活性になると考えられる は, 灰分や不純物元素の影響を抜きにしても, 無定形炭 素から黒鉛化度の高い結晶まで進化の度合いの異なるさ まざまな結晶が存在し, さらにこれが高炉内の温度変化 に応じて刻々変化することによると考えられる．また， コークスによってばらつきが大きいのも，原料や製造履 歴によって, 結晶性が大きく異なるためとも考えられる.

これまで, コークスの反応性と結晶の黒鉛化過程は個 別に議論されてきた。 また，速度論的な取扱いにおいて も, 炭素の結晶学的な多様性は考慮されず, 均一なもの として解析が行われてきた. 本研究では, X 線回折に よって, コークス中結晶子の大きさに与える温度とガス 化反応の影響を調査し，これに基づいてコークスの微視 的反応機構について考察した。 さらに, 炭素が結晶と非 結晶で反応性が異なり, それらの存在比率は温度で変化 するとした反応モデルをたて, 速度解析を行った。

平成元年 9 月本会講演大会にて発表 平成元年 12 月 11 日受付 (Received Dec. 11, 1989)

* 北海道大学工学部 (Faculty of Engineering, Hokkaido University, Kita 13-jo Nishi 8-chome Kita-ku Sapporo 060)

*2 北海道大学工学部 工博 (Faculty of Engineering, Hokkaido University) 


\section{2. 炭素の結晶性を考慮したコークスの ガス化モデル}

後述するように, 実際のコークス中炭素は, 進化の度 合いの異なるさまざまな結晶からなっている，しかし， 本研究では, 製鉄用コークスのガス化速度解析の第一歩 として,コークス中の炭素を, X 線の回折に寄与する 黒鉛結晶（結晶子, Crystalline carbon) と, 回折には寄 与せず, Background 強度だけに関係する無定形炭素 （非結晶炭素, Non-crystalline carbon) に二分し, 簡単 化したモデルをたてた. コークスのガス化反応と，同時 進行する黒鉛化反応の関係を Fig. 1 に示す. 反応の速 い無定形炭素と, 反応の遅い黑鉛化した結晶のガス化反 応が，それぞれ独立に進行する (1)，(2)). 同時に，反 応温度に依存して，無定形炭素が結晶に組み込まれて減 少する (3)).ここでは, (3)の反応は速く, 反応温度に 到達するやその温度に相当する分だけ結晶子に変化する ものとして反応解析を行った.

\section{$2 \cdot 1$ 昇温にともなうコークス中炭溱結晶子の変化とガ ス化反応機構}

昇温による炭素結晶子の変化と, これに対するガス化 反応の影響を調査するため, 試料の X 線回折を行った.

Fig. 2 ( a ) に黒鉛結晶の模式図と単位格子を示した. 結晶子の大きさは, 炭素網目平面の広がり $(L a)$ と, そ の積み重なり厚さ $(L c)$ によって表すことができる ${ }^{8)}$. Fig. 2 ( b ) に結晶子の概念図と $L a, L c$ の関係を示し

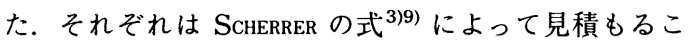
とができる.

$$
L_{h k l}=A \lambda /(B \cos \theta)
$$

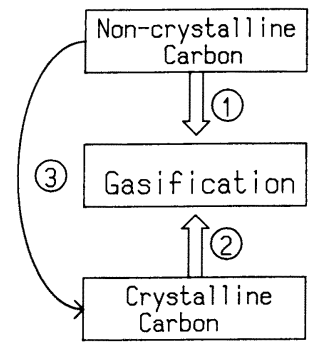

Fig. 1. Processes of gasification and crystallization of carbon.
ここで, $A$ は回折面によって決まる定数, 入はX 線の 波長 ( $\mathrm{A}), B$ はピークの半価幅 $(\mathrm{rad}), \theta$ はピークの 位置である. 通常 (100) 反射と（101）反射のピークは, 黒鉛化度の低い炭素においては重なり合うため（10）反 射と表記される.

実験前の試料コークスとこれを $\mathrm{Ar}$ 気流中, $1450^{\circ} \mathrm{C}$ で, $1 \mathrm{~h}$ 熱処理したコークスの粉末 $\mathrm{X}$ 線回折パターン を Fig. 3 に示した. Table 1 に示したように, コーク ス中の不純物は, $\mathrm{SiO}_{2}, \mathrm{Al}_{2} \mathrm{O}_{3}$ の順に多い.このうち, $\mathrm{SiO}_{2}$ は, Quartz (ASTM, 33-1162) の形で存在してい るのがわかる3).

実験前のコークスは, (002) 反射のピークがブロード

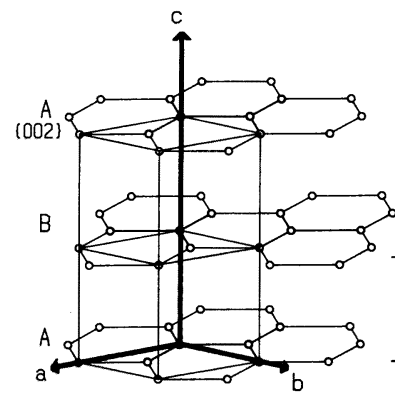

(a)

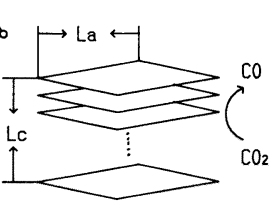

(b) (a) Unit cell of graphite crystal

(b) Relationship between crystallite and $L a, L c$

Fig. 2. Schematic diagrams of graphite crystallite.

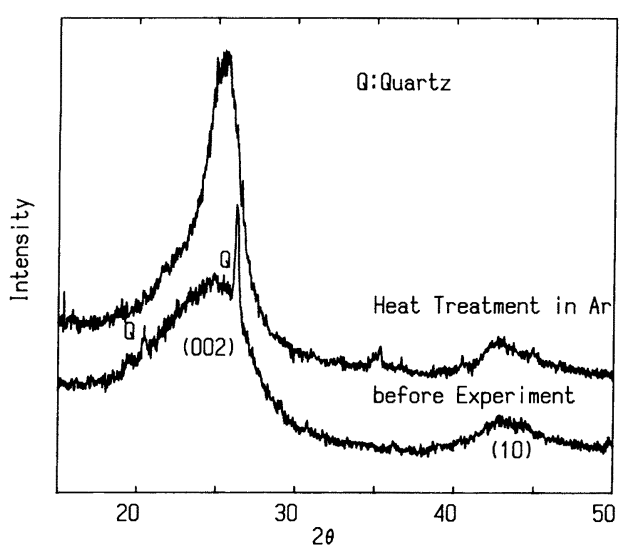

Fig. 3. X-ray diffraction patterns of heat treated and non-treated metallurgical coke.

Table 1. Chemical composition and physical properties of metallurgical coke.

\begin{tabular}{|c|c|c|c|c|c|c|c|c|c|c|}
\hline \multicolumn{8}{|c|}{ Chemical composition (wt\%) } & \multirow{2}{*}{$\begin{array}{c}\text { Apparent } \\
\text { density } \\
\left(\mathrm{g} / \mathrm{cm}^{3}\right)\end{array}$} & \multirow{2}{*}{$\underset{(\mathrm{mm})}{\text { Mean }}$} & \multirow{2}{*}{$\begin{array}{c}\text { Void } \\
\text { fraction } \\
(-)\end{array}$} \\
\hline T. Fe & $\mathrm{SiO}_{2}$ & $\mathrm{Al}_{2} \mathrm{O}_{3}$ & $\mathrm{CaO}$ & $\mathrm{MgO}$ & S & $\underset{\mathrm{C}}{\text { Fixed }}$ & $\begin{array}{l}\text { Volatile } \\
\text { matter }\end{array}$ & & & \\
\hline 1.1 & 6.0 & 3.3 & 0.3 & 0.2 & 0.7 & 87.5 & 0.9 & 1.05 & 1.59 & 0.495 \\
\hline
\end{tabular}




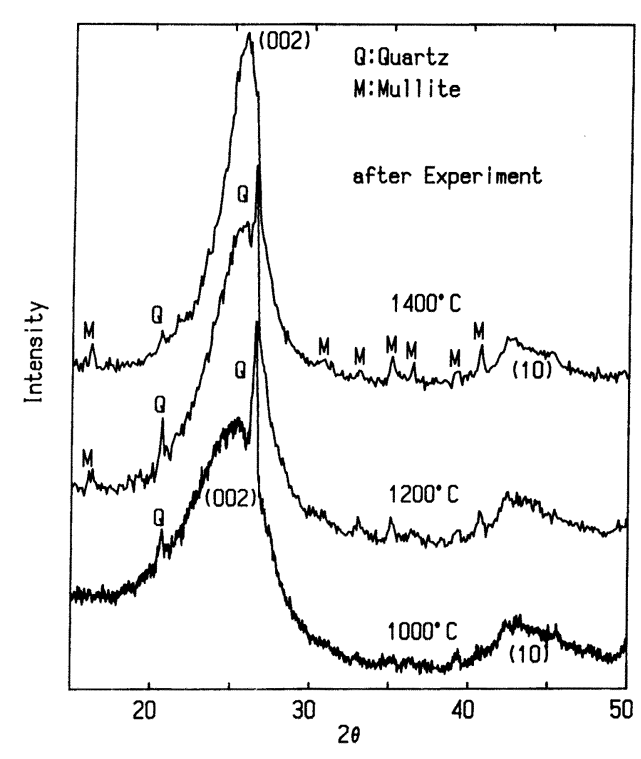

Fig. 4. X-ray diffraction patterns of metallurgical coke at various reaction temperatures.

であり，Lcが小さいことを示す.これを熱処理すると ピークはシャープになり $L c$ が成長したことがわかる.

$L a$ に対応する（10）反射も，熱処理後にややシャープ になっており, 結晶子が全体として成長していることが わかる.

ガス化後の試料 (ガス化率 10〜30\%, 詳細は後述) の $\mathrm{X}$ 線回折パターンを Fig. 4 に示した. $1000^{\circ} \mathrm{C}$ におい ても，まだ (002) 回折ピークはブロードであるが, 反 応温度が高くなるにつれ，ピークはシャープになり結晶 子 $(L c)$ が成長しているのがわかる. $1400^{\circ} \mathrm{C}$ のガス化 後に, Quartzは灰分中の $\mathrm{Al}_{2} \mathrm{O}_{3}$ と反応して, Mullite (ASTM，15-776）を形成しているのが明暸に確認でき $\Xi^{3)}$.

これらピークの半価幅から(1)式によって $L c, L a$ を求め, Fig. 5, Fig. 6 に実験温度による違いを示した.

Fig. 5 に示すように, ガス化後の Lc の変化 (O) は, 実験温度に対してほぼ直線的に大きくなっている.また, Ar 気流中で熱処理した場合 $(\square: 60 \mathrm{~min}, \square: 5 \mathrm{~min})$ もこの直線上にあり, $L c$ は雲囲気および反応の有無に 関係なく温度によって決まるものと思われる.これに対 して, Fig. 6 に示したように, La は, 反応後に小さくなっ ている.このことは, ガス化反応が結晶学的な選択性を もって進行していることを示している. すなわち，ガス 化反応は (002) 面 (炭素網目平面) に対しては遅く, (002) 面に垂直な面に対して優先的に生じることを意味

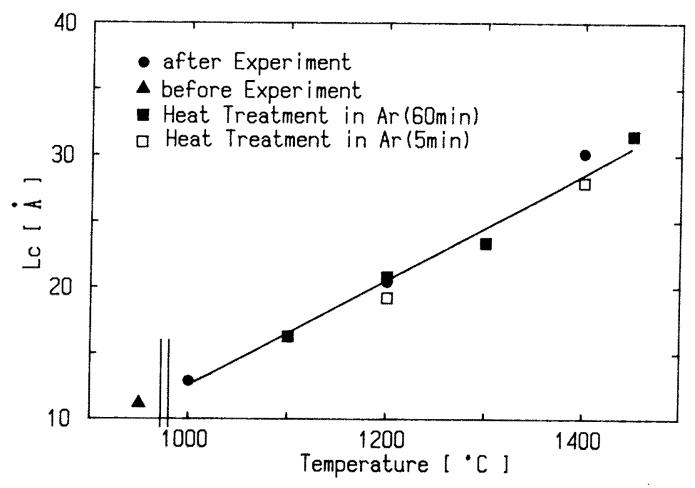

Fig. 5. Relationship between $L c$ and temperature.

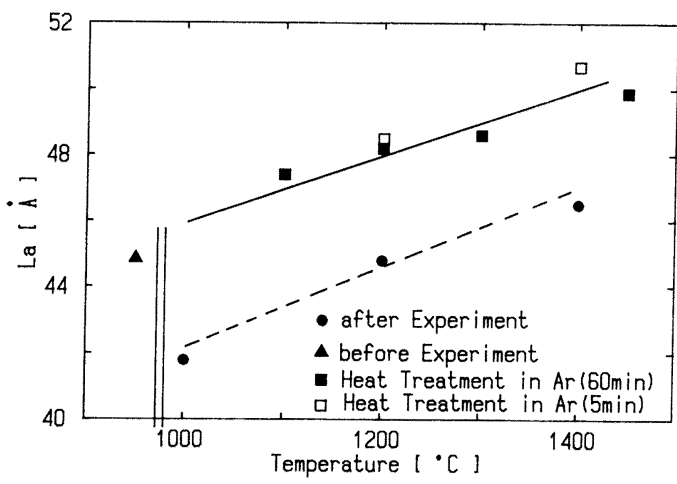

Fig. 6. Relationship between $L a$ and temperature.

すると思われる．これらのことから， $\mathrm{CO}_{2}$ によるコー クスのガス化反応機構を推測すれば次のようになる.

a) ガス化反応には, 結晶学的な選択性があり, Fig. 2 （b）に示すように，一つの結晶子の側面から進行してい く. 結果として $L a$ は小さくなる.

b)炭素網目平面の積み重なり $L c$ は, 反応に関係なく ガス化温度によって決まる.

ガス化反応の最初の素過程は $\mathrm{CO}_{2}$ の吸着であるが, 一つの結晶子において, 最も多くの吸着サイトを供給し 得るのは, 炭素網目平面内の欠陥よりも,むしろ側面に 存在する不対結合 (Dangling bond) であると考えられ る.

\section{$2 \cdot 2$ 速度解析の方法}

$2 \cdot 2 \cdot 1$ 炭素の結晶性を考慮した速度式

Langmuir-Hinshelwood 型 (L-H 型) の速度式を用い る場合, 数種の反応機構 ${ }^{11)}$ が提出されている. 前述の 結果から本研究では, 炭素網目平面の周辺に存在する不 対結合を持った炭素が吸着サイトになっているものと仮 定する. $\mathrm{CO}_{2}$ はこの炭素に吸着し,これが最初の素反応 
となると考える. $\mathrm{CO}_{2}$ と黒鉛結晶の各原子間距離とそれ ぞれの幾何学的配置は以下のようになっている.

I. $\mathrm{CO}_{2}$ は $\mathrm{C}$ と O が一直線上に並んでおり, その原 子間距離は $1.16 \AA$, $\mathrm{O}$ と $\mathrm{O}$ の距離は $2.32 \AA$ である ${ }^{14)}$.

II. 黒鉛結晶では, 網目平面内の C-C 結合の長さは, $1.42 \AA$ であり, 層間距離は, $3.35 \sim 3.44 \AA$ である ${ }^{8)}$. これらを考慮にいれ, Fig. 7 のような反応機構を考える.

(1) $\mathrm{CO}_{2}$ が不対結合を持った炭素 $\left(\mathrm{C}_{f}\right)$ に吸着する (( 2 )式).このとき, $\mathrm{CO}_{2}$ のどちらか一方の $\mathrm{O}$ だけが 吸着する. 上述の原子間距離と幾何学的配置からして, 両方の 0 が同時に吸着する確率は低い.

(2)吸着した $\mathrm{CO}_{2}$ は解離して $\mathrm{CO}$ ガスを放出する (( 3 )式).

(3)吸着した $\mathrm{O}$ と $\mathrm{C}_{f}$ が, $\mathrm{CO}$ ガスとなる (( 4 )式).

(4)不対結合を持った炭素への CO ガスの吸着脱離反 応も, 同時に起こる $\left((2)^{\prime}\right.$ 式).

以上の素反応を式に書くと, (2) （4)式の逐次反応お よび ( 2 )’式となる.

$$
\begin{aligned}
& \mathrm{C}_{f}+\mathrm{CO}_{2(\mathrm{~g})} \stackrel{i_{13}}{\stackrel{i_{2}}{\rightleftarrows}} \mathrm{C}\left(\mathrm{CO}_{2}\right) \\
& \mathrm{C}\left(\mathrm{CO}_{2}\right) \stackrel{i_{3}}{\longrightarrow} \mathrm{C}(\mathrm{O})+\mathrm{CO}_{(\mathrm{g})} \\
& \mathrm{C}(\mathrm{O}) \stackrel{i_{4}}{\longrightarrow} \mathrm{CO}_{(\mathrm{g})} \\
& \mathrm{C}_{f}+\mathrm{CO}_{(g)} \underset{i_{6}}{\stackrel{i 5}{\rightleftarrows}} \mathrm{C}(\mathrm{CO})
\end{aligned}
$$

ここで， $\mathrm{C}_{f}$ は不対結合を有する炭素で, 吸着サイトを 表す. $\mathrm{C}(\mathrm{O}), \mathrm{C}(\mathrm{CO}), \mathrm{C}\left(\mathrm{CO}_{2}\right)$ はそれぞれ吸着した $\mathrm{O}, \mathrm{CO}, \mathrm{CO}_{2}$ を示す.

全吸着サイトの数を濃度 $\left(C_{T}, \mathrm{~mol} / \mathrm{cm}^{3}\right)$ として表し, 結晶子の密度 $\rho_{0}$ で割って無次元化 $\left(S_{T}=12 C_{T} /\left(\rho_{0}\right)\right.$, [一]) する. この無次元吸着サイト濃度 $S_{T}$ は, 炭素原 子 1 個当たりの吸着サイトの数を意味する.

$$
S_{T}=S_{\theta}+S_{f}
$$

ここで, $S_{\theta}\left(=S_{\mathrm{CO}_{2}}+S_{\mathrm{CO}}+S_{\mathrm{O}}\right)$ は原子, 分子によっ
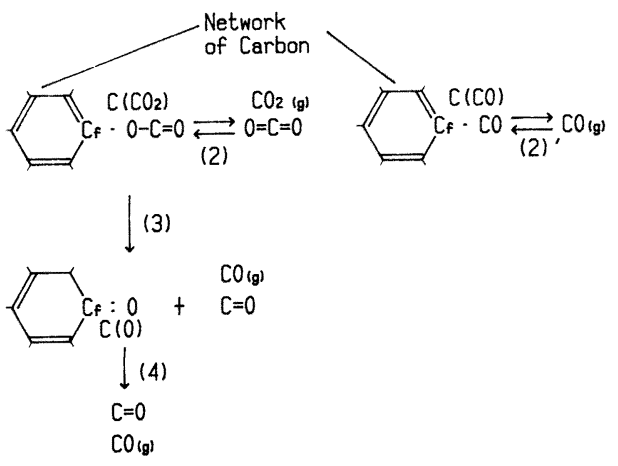

Fig. 7. Schematic diagram of elementary reactions related with graphite crystalline characteristic.
て占められた吸着サイトおよび $S_{f}$ は未反応の吸着サイ トを表す。いま，(4)式を律速反応 ${ }^{11)}$ として速度式を 求める。（2), ( 2$)^{\prime}$, ( 3 ) より,

$$
\begin{aligned}
& i_{1} P_{\mathrm{CO}_{2}} S_{f}=i_{2} S_{\mathrm{CO}_{2}}+i_{3} S_{\mathrm{CO}_{2}} \\
& i_{3} \mathrm{~S}_{\mathrm{CO}_{2}}=i_{4} S_{\mathrm{O}} \\
& i_{5} P_{\mathrm{CO}} S_{f}=i_{6} S_{\mathrm{CO}}
\end{aligned}
$$

また，全反応速度 $k$ は，

$$
k=i_{4} S_{\mathrm{o}}
$$

である.（6)〜（８)式を用いて（9)式を変形すると，

$$
\begin{aligned}
k & =i_{1} i_{3} /\left(i_{2}+i_{3}\right) P_{\mathrm{CO}_{2}} S_{f} \\
& =k_{1} S_{T} P_{\mathrm{CO}_{2}} /\left(1+k_{2} P_{\mathrm{CO}}+k_{3} P_{\mathrm{CO}_{2}}\right)
\end{aligned}
$$

となり, 従来の $\mathrm{L}-\mathrm{H}$ 型の速度式に, 全吸着サイトの数 が導入された式となった.ここで， $k_{1}=i_{1} i_{3} /\left(i_{2}+i_{3}\right)$, $k_{2}=i_{5} / i_{6}, k_{3}=\left(i_{1} i_{3}+i_{1} i_{4}\right) /\left(i_{2} i_{4}+i_{3} i_{4}\right)$ であり, $P_{\mathrm{CO}}$, $\mathrm{P}_{\mathrm{CO}_{2}}$ は，それぞれ $\mathrm{CO}, \mathrm{CO}_{2}$ の分圧 $(\mathrm{atm})$ である.

炭素が結晶, 非結晶にかかわらず, 基本的にこの反応 機構は変わらないものと考える。.上述したように，ガス 化反応は一つの結晶子の側面においてのみ進行すると仮 定すると, 炭素原子 1 個当たりの吸着サイト数は, 炭素 網目平面が大きくなる $(L a$ が大きくなる) ほど少なく なる. すなわち，コークス中の炭素を無定形炭素と結晶 性炭素に大別したとき, 前者の方が炭素原子 1 個当たり の吸着サイト数 $\left(S_{T}\right)$ が多くなり, 反応速度も速くなる.

いま，結晶·非結晶それぞれの吸着サイト数は不明で ある. したがって, 本研究では二種類の炭素の反応性を 個別に評価するため， $k_{1}$ と $S_{T}$ を一つにまとめ，結晶・ 非結晶それぞれについて次のように表記する.

$$
\begin{aligned}
& k_{C}=k_{1, C} \cdot P_{\mathrm{CO}_{2}} /\left(1+k_{2} P_{\mathrm{CO}}+k_{3} P_{\mathrm{CO}_{2}}\right) \cdots \cdots \cdots(10) \\
& k_{a}=k_{1, a} \cdot P_{\mathrm{CO}_{2}} /\left(1+k_{2} P_{\mathrm{CO}}+k_{3} P_{\mathrm{CO}_{2}}\right) \cdots \cdots \cdots(11) \\
& 2 \cdot 2 \cdot 2 \text { 速度解析 }
\end{aligned}
$$

化学反応過程に基づいて速度解析する場合, 単位べッ ド体積当たりのガス化反応速度 $R_{G}\left(\mathrm{~mol} / \mathrm{s} / \mathrm{cm}^{3}-\mathrm{bed}\right)$ は 末反応率に比例するものとした， $C_{0}, C$ はそれぞれ時 間 $t=0, t=t$ における炭素濃度 $\left(\mathrm{mol} / \mathrm{cm}^{3}-\mathrm{bed}\right)$ であ る. $X\left(=\left(W_{0}-W\right) / W_{0}, W_{0}, W:\right.$ 時間 $t=0, t=t$ における炭素質量 $(\mathrm{g}))$ は反応率である.

$$
R_{G} \equiv-d C / d t=k C=k(1-X) C_{0}
$$

上述したように, 結晶子の遅い反応と無定形炭素の速 い反応が独立に進行するとすると，次のようになる.

$$
\begin{aligned}
& R_{G, C} \equiv-d C_{C} / d t=k_{C}\left(1-X_{C}\right) C_{C, 0} \\
& R_{G, a} \equiv-d C_{a} / d t=k_{a}\left(1-X_{a}\right) C_{C, 0}
\end{aligned}
$$

ここで, $k_{C}, k_{a}$ はそれぞれ結晶子と無定形炭素の見 掛けの速度定数（(10)，（11)式）を表す。また， $X_{C}=$ $\left(W_{C, 0}-W_{C}\right) / W_{C, 0}, X_{a}=\left(W_{a, 0}-W_{a}\right) / W_{a, 0}$ である. 下付き添え字 $a, C$ は, それぞれ, 結晶子と無定形炭 
素を示し， 0 は時間 $t=0$ における量を示す.

計算に先だってあらかじめ求めておかなければならな い值は, 結晶子と無定形炭素の初期の重量 $\left(W_{C, 0}, W_{a, 0}\right)$ である. Fig. 5, Fig. 6 からわかるように Lc, La は, 反応がない場合, 温度 $\left(1000 \sim 1400^{\circ} \mathrm{C}\right)$ とほほ直線的 な関係にある. $L a, L c$ を温度の一次関数として, 1000 $\sim 1400^{\circ} \mathrm{C}$ の間で, 結晶子と無定形炭素の初期の重量 を次式から見積もり, 全重量に対する割合 $\left(N_{C}=W_{C, 0}\right)$ $\left.W_{0}, N_{a}=W_{a, 0} / W_{0}\right)$ を求めた. 結果を Fig. 8 に示す.

$$
\begin{aligned}
& n_{C}=W_{0} /\left(V_{C} \cdot \rho_{0}\right) \quad\left(V_{C}: \text { at } 1400^{\circ} \mathrm{C}\right) \\
& W_{C, 0}=n_{C} \cdot V_{C} \cdot \rho_{0} \\
& W_{a, 0}=W_{0}-W_{C, 0}
\end{aligned}
$$

ここで, $n_{C}$ は結晶子の個数である. $1000^{\circ} \mathrm{C}$ 以上で新 たな核生成は起こらず, 結晶子の個数は一定で, 大きさ だけが変化すると仮定し，さらに無定形炭素は $1400^{\circ} \mathrm{C}$ ではすべて結晶に組み込まれる $\left(N_{a}=0\right)$ とした.

また， $V_{C}\left(=L c \cdot L a^{2} \cdot(\sqrt{3} / 2) \times 10^{-24}\left[\mathrm{~cm}^{3}\right]\right)$ は結 晶子の体積である. 本研究の温度範囲で, 結晶子の密度 を $\rho_{0}=2.21\left(\mathrm{~g} / \mathrm{cm}^{3}\right)$ とした ${ }^{8)}$.

試料充填層をいくつかの小区間に分割したとき，区間 内に拈けるガス側各成分の収支はガス化反応の速度 $R_{G}$ (= $R_{G, a}+R_{G, C}: \mathrm{mol} / \mathrm{s} / \mathrm{cm}^{3}$-bed) を用いて以下のよう に表される.

$$
\begin{aligned}
& u\left(\partial P_{\mathrm{Co}} / \partial z\right)+\varepsilon\left(\partial P_{\mathrm{Co}} / \partial t\right)=2 \cdot R_{G} \cdot R T \cdot \cdot(18) \\
& u\left(\partial P_{\mathrm{CO}_{2}} / \partial z\right)+\varepsilon\left(\partial P_{\mathrm{CO}_{2}} / \partial t\right)=-R_{G} \cdot R T \cdots(19)
\end{aligned}
$$

一方，コークス中炭素に関するマスバランスは, $(20)$,

(21)式である.

$$
\begin{aligned}
& \partial X_{C} / \partial t=R_{G, C} \cdot 12 / C_{C, 0} \\
& \partial X_{a} / \partial t=R_{G, a} \cdot 12 / C_{a, 0}
\end{aligned}
$$

ここで, $P$ : 各成分の分圧 $(\mathrm{atm}), u$ : 空塔速度 $(\mathrm{cm} / \mathrm{s})$, $\varepsilon$ : 空隙率 $(-), z:$ ガス流れ方向の距離 $(\mathrm{cm}), R, T$ は気体定数と絶対温度である。これら(13)，(14)，(18)

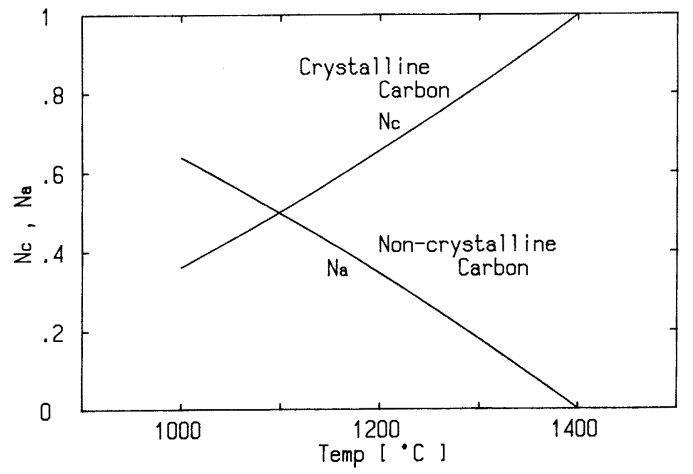

Fig. 8. Variation of $N_{a}, N_{C}$ with temperature.
～(21)式を連立して解くことにより解析を進めた。この 際，常微分化には特性曲線法を用いた。

\section{3. 実験装置および方法}

Fig. 9 に実験装置の概略を示す．各成分のガスは熱質 量型流量制御器 (MFC) によって目的の組成に流量調整 された後, 混合器を通して反応ガスとした，反応ガスの 分析は, $\mathrm{CO}$ と $\mathrm{CO}_{2}$ の二台の赤外線ガス分析計を使用 した. 分析計の較正は, MFC と湿式ガス流量計を用い て生成ガスに近い組成に調整した標準ガスを用いて行っ た。

反応炉は，複螺管型 $\mathrm{SiC}$ 発熱体を使用した縦型の電 気炉でこの中に両端を $\mathrm{O}$ リングシールしたムライト 製反応管 (内径 $35 \mathrm{~mm} \times$ 長さ $600 \mathrm{~mm}$ ) が設置されてい る. 試料容器は内径 $20 \mathrm{~mm}$ のアルミナ管で, 途中をア ルミナの目皿で仕切って, 深さ $40 \mathrm{~mm}$ のるつほとした. この中にコークス試料 $(5 \mathrm{~g})$ を入れ, 約 $30 \mathrm{~mm}$ の充填 層を形成させた.

試料は，製鉄用コークスを 9〜16 mesh に破砕したも のを熱処理せずに用いた。試料コークスの諸性質を Table 1 に示す.

反応ガス流量は, $2000 \mathrm{~cm}^{3} / \mathrm{min}$ (STP)（空塔速度約 $11 \mathrm{~cm} / \mathrm{s}$ ) を標準とし, 一部流量を増減させ, 固定層と しての特性について検討した，温度は，高炉の化学保 存帯より下部の領域を想定して, $1000^{\circ} \mathrm{C}, 1200^{\circ} \mathrm{C}$, $1400^{\circ} \mathrm{C}$ の 3 水準とした。 ガス組成は, CO $0 \sim 40$ vol\%, $\mathrm{CO}_{2}$ を 2 30 vol\% の間で変化させ，適宜 $\mathrm{CO} / \mathrm{CO}_{2}$ を変え,残りを $\mathrm{Ar}$ で希釈した. 圧力は, $0.1 \mathrm{MPa}(1 \mathrm{~atm})$

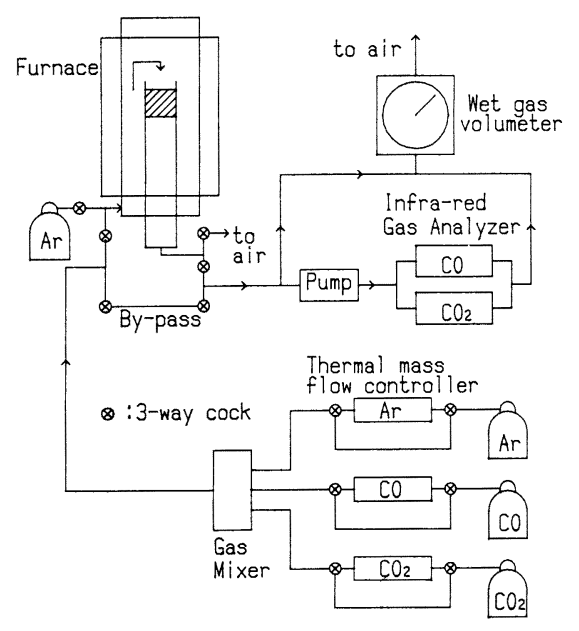

Fig. 9. Schematic diagram of experimental apparatus. 
とした.

\section{4. 結果と考察}

\section{$4 \cdot 1$ 反応諸因子のガス化速度に対する影響}

Fig. 10 に, $1000,1200,1400^{\circ} \mathrm{C}$ における層平均ガス 化速度 $(R C S[1 / \mathrm{s}])$ を反応ガス $\left(\mathrm{CO}, \mathrm{CO}_{2}\right)$ 濃度に対し て示した。これらの影響をまとめると次のようになる.

a) $\mathrm{CO}_{2}$ の影響

i)低 $\mathrm{CO}_{2}$ 濃度 $(<10 \%)$ において, ほほ直線的に反応 速度が増加する.

ii)高濃度域では, 曲線の勾配は小さくなり, $\mathrm{CO}_{2}$ の 抑制効果が存在することを示す.

iii) $\mathrm{CO}_{2}$ の抑制効果は, 低温 $\left(1000^{\circ} \mathrm{C}\right)$ ほど顕著であ り，高温になるほど小さい，

\section{b)CO の影響}

i)CO には反応の抑制効果があり, 低 $\mathrm{CO}$ 濃度ほど, この抑制効果は顕著である.

ii) 高温 $\left(1400^{\circ} \mathrm{C}\right)$ になると $\mathrm{CO}$ の抑制効果は，ほと んど見られなくなる.

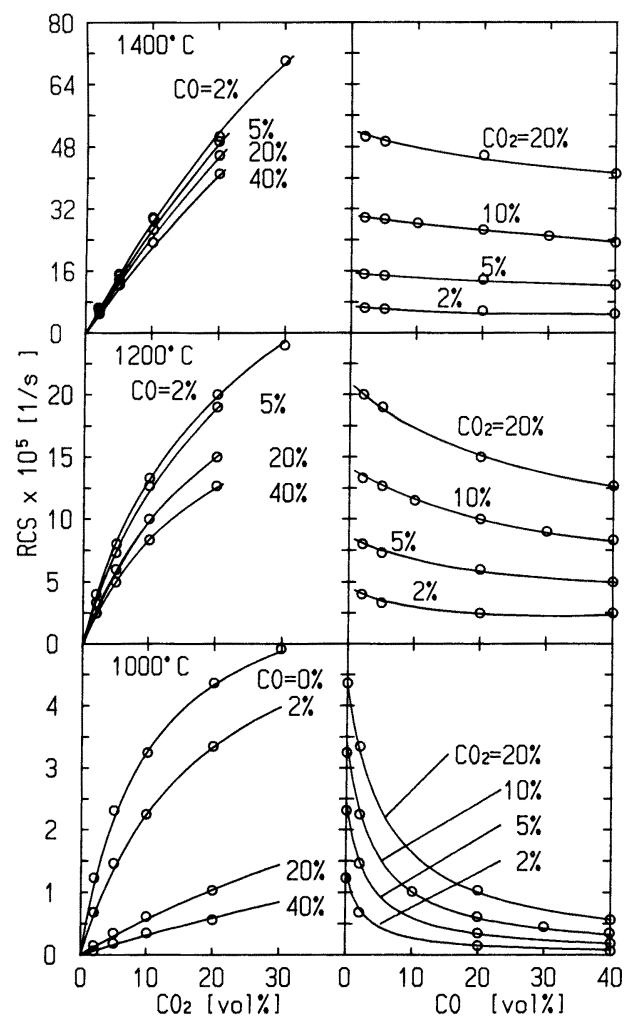

Fig. 10. Variation of RCS with experimental conditions.
$\mathrm{CO}$ に反応阻害効果が認められることから，本実験の ような固定層型の反応では, 反応ガスの層内組成变化を 考慮にいれた解析が必要であると考えられる.

\section{$4 \cdot 2$ 速度定数の決定}

本研究の反応が，ガス境膜内物質移動によって支配さ れているかどうか検討した ${ }^{12)}$. RANZ の式 ${ }^{13)}$ から計算さ れる物質移動係数から求められた物質移動量は, 実測の 層平均反応速度の約 100 倍であった。これは, 混合律 速式による精確な計算ではないが, 気相内の物質移動に 基づく抵抗はほぼ無視し得ることを意味している.また， 本研究において反応ガスの流量を増加させた場合, 反応 速度は増加したが，層内のガス濃度分布が改善されたた めであり，固定層としての特徴を反映したものと考えら れる. 事実，計算值は実測值とよい一致を示した ${ }^{12)}$.

また，粒子内ガス拡散律速を仮定し，小林ら ${ }^{15)}$ の有 効拡散係数を用いて反応速度を概算した $\left(1000^{\circ} \mathrm{C}\right.$, $\left.P_{\mathrm{CO}_{2}}=0.2, P_{\mathrm{CO}}=0\right)$ ．このとき計算された值は, 実測 の 120 倍であり, 本実験における気孔内ガス拡散の寄 与は無視できるものと考えられる.

試行錯誤法によってパラメーターフィッティングを行 うに先だって，あらかじめパラメーターの近似值を求め ておくことは重要である. なぜなら，パラメーターの数 が多い場合には, 現象にそぐわない無意味な数值を得る 危険性があるからである。

本研究では, 次の二つの仮定に基づいて近似值を求め た.

(1) $C_{C}, C_{a}$ は一定 $\left(C_{C}=C_{C, 0}, C_{a}=C_{a, 0}\right)$.

(2)層内ガス組成一定 (ガス組成は入口, 出口の平均を 用いる).

観測される速度曲線の極く初期 $(\fallingdotseq 60 \mathrm{~s})$ においては, (1)が成り立ち，(13)，(14)式は次のように書ける.

$$
-d C_{C} / d t \doteqdot k_{C} \cdot C_{C, 0}
$$

$$
-d C_{a} / d t \doteqdot k_{a} \cdot C_{a, 0} \cdots
$$

したがって, 見掛けの反応速度は,

$-d C / d t \doteqdot k_{C} \cdot C_{C, 0}+k_{a} \cdot C_{a, 0}$

$$
=\left(k_{1, C} C_{C, 0}+k_{1, a} C_{a, 0}\right) P_{\mathrm{CO}_{2}} /\left(1+k_{2} P_{\mathrm{CO}}\right.
$$$$
\left.+k_{3} P_{\mathrm{C}_{2}}\right)
$$

$R C S=-(d C / d t) \cdot 12 \cdot V_{B} / W_{0}$

$$
\begin{aligned}
= & \left(N_{C} k_{1, C}+N_{a} k_{1, a}\right) P_{\mathrm{CO}_{2}} /\left(1+k_{2} P_{\mathrm{CO}}\right. \\
& \left.+k_{3} P_{\mathrm{CO}_{2}}\right) \\
= & k_{0} \cdot P_{\mathrm{CO}_{2}} /\left(1+k_{2} P_{\mathrm{CO}}+k_{3} P_{\mathrm{CO}_{2}}\right) \cdots
\end{aligned}
$$

$$
\text { ここで, }
$$

$$
\begin{aligned}
k_{0}= & N_{C} k_{1, C}+N_{a} k_{1, a} \\
N_{i}= & C_{i, 0} 12 V_{B} / W_{0} \\
& \left(i=C \text { or } a, V_{B}: \text { bed } \text { の体積 }\right)
\end{aligned}
$$


である。

ガス化速度の実測值 $(R C S)$ から, (25) 式の速度定数 を決定した（25)式の逆数が $1 / P_{\mathrm{CO}_{2}}$ と $P_{\mathrm{CO}} / P_{\mathrm{CO}_{2}}$ の 線形関数であることに着目して, 重回帰分析を行い, $k_{0}$ ， $k_{2}, k_{3}$ を求めた。 $P_{\mathrm{CO}}, P_{\mathrm{CO}_{2}}$ は, 層入口と出口の平均 のガス組成を用いた (仮定(2)). $k_{1, C}, k_{1, a}$ は，(26)式か ら求めるが, このとき $1400^{\circ} \mathrm{C}$ では， $N_{a}=0$ であるこ とから， $1400^{\circ} \mathrm{C}$ の $k_{0}$ を $k_{1, C}$ として用いた $\left(k_{1, C}=\right.$ $\left.k_{0}\right)$. 得られた $k_{1, C}, k_{1, a}, k_{2}, k_{3}$ の近似值を出発值と して, 固定層としての計算を行い, 反応率および出口ガ ス組成の計算值が実測值に合うようにパラメーター フィッティングを行い $k_{1, C}, k_{1, a}, k_{2}, k_{3}$ を求めた。 な お, 本計算は, 層高を 30 分割, 時間間隔 $20 \mathrm{~s}$ で収束 した.

Fig. 11 に各温度で得られた速度定数 $\left(k_{1, C}, k_{1, a}\right.$ $\left.\left(\mathrm{s}^{-1} \cdot \mathrm{atm}^{-1}\right), k_{2}\left(\mathrm{~atm}^{-1}\right), k_{3}\left(\mathrm{~atm}^{-1}\right)\right)$ を丸印 (O) で 示した。各速度定数の温度依存性は, 次のようになる.

$$
\begin{aligned}
& k_{1, C}=\exp (9.49-24200 / T) \\
& k_{1, a}=\exp (4.19-13400 / T) \\
& k_{2}=\exp (-17.7+27700 / T) \\
& k_{3}=\exp (-1.59+5680 / T)
\end{aligned}
$$

これらを, 小林ら ${ }^{1)}$ (破線), ADERIBIGBE ら²) (一点鎖線)

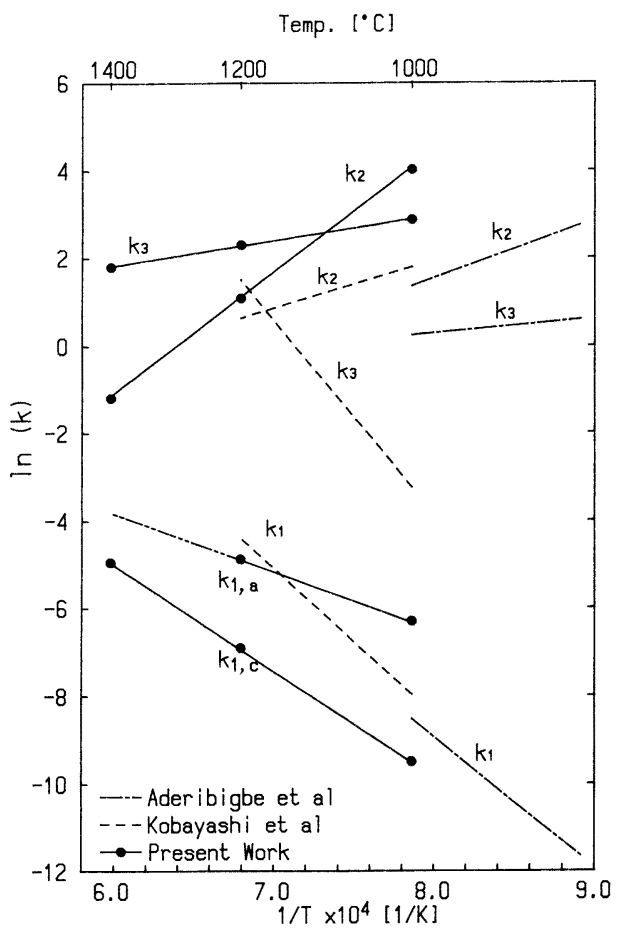

Fig. 11. Arrhenius plot of rate constants.
の研究と比較した. 本研究の $k_{1, a}$ 值は, 他の研究者ら の $k_{1}$ 值より大きく, $k_{1, c}$ は小さい. コークスの反応性 の違いを結晶・非結晶割合 $\left(N_{C}, N_{a}\right)$ で評価すれば，本 研究の速度定数を用いて異なるコークスの反応速度を表 し得る可能性があることを示している．また，高炉内の コークスの反応挙動を研究する場合, 温度履歴が結晶・ 非結晶割合に影響することから，高温で熱処理したコー クスの反応は，実炉には適用できないものと思われる. なお， $k_{2}, k_{3}$ は, 高温で $\mathrm{CO}, \mathrm{CO}_{2}$ の反応阻害効果 が小さくなった実験事実 (Fig. 10) を反映して, 温度 係数が正の值となっている. 得られた速度定数を用いて 計算した結果を，実測值と比較して，Fig. 12, Fig. 13, Fig. 14 に示した.

Fig. 12 は $1000^{\circ} \mathrm{C}, 20 \% \mathrm{CO}_{2}-0 \% \mathrm{CO}$ の実験である. 破線は, 結晶子の反応速度 $\left(R C S_{C}\right)$, 一点鎖線は無定形 炭素の反応速度 $\left(R C S_{a}\right)$ の計算値である. 実線は, 層 平均の反応速度 $(R C S)$ と反応率 $(T C S)$ の計算値であ $\eta$, 実験值とよく合っている.

Fig. 13 は $1200^{\circ} \mathrm{C}, 20 \% \mathrm{CO}_{2}-2 \% \mathrm{CO}$ の実験である. この場合，反応速度が大きく，反応率 $30 \%(2000 \mathrm{~s})$ を

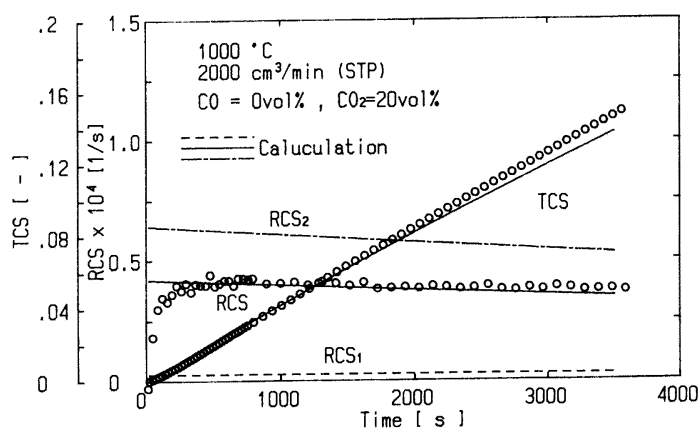

Fig. 12. Comparison between calculated results and observed data $\left(1000^{\circ} \mathrm{C}\right)$.

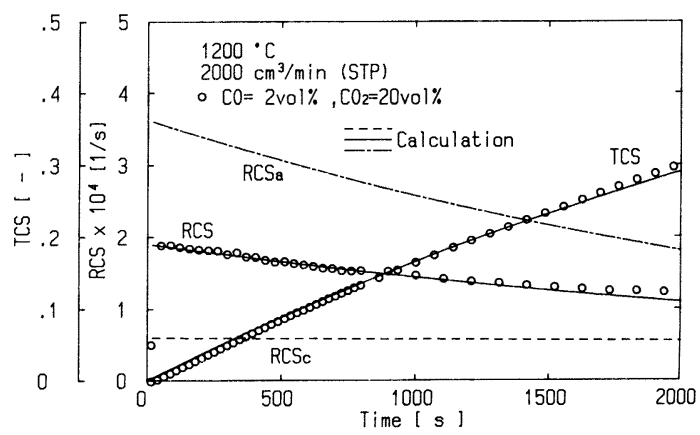

Fig. 13. Comparison between calculated results and observed data $\left(1200^{\circ} \mathrm{C}\right)$. 


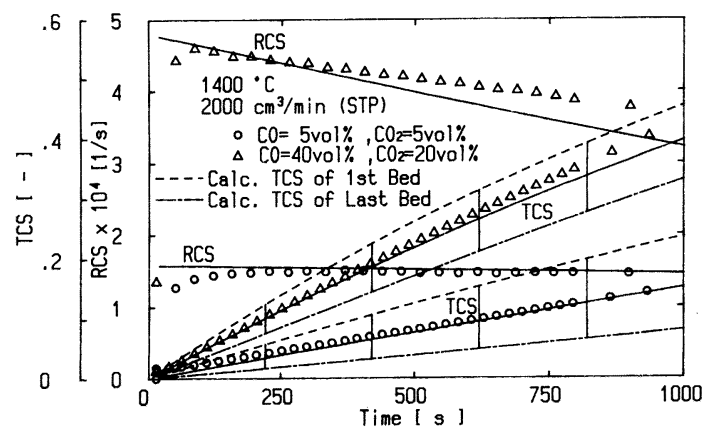

Fig. 14. Comparison between calculated results and observed data $\left(1400^{\circ} \mathrm{C}\right)$.

超えると合わなくなる，これは，a)層下部では反応が終 了に近くなり，Ash 層が出現する，b）それに伴い，反 応層の高さが低くなる，などの理由による. $1000^{\circ} \mathrm{C} に$ おいて, 結晶子の反応速度 $\left(R C S_{C}\right)$ は, 非常に小さく, 全体の速度に占める割合も少ない。これに比べて $1200^{\circ} \mathrm{C}$ では，かなり大きくなってくるが，この実験時 間の範囲では，ほほ一定の值である．また，無定形炭素 の反応速度 $\left(R C S_{a}\right)$ は，単調減少を示しており，反応 速度曲線 $(R C S)$ の特徴は, $R C S_{a}$ の形状を強く反映し ていると言える.

Fig. 14 は $1400^{\circ} \mathrm{C}$ の実験で, 反応が速いガス組成 $(\triangle)$ と遅いガス組成 $(\bigcirc)$ の両方の実験結果を示した. 計算值はすべて線で示されており，反応率は層平均の反 応率 (実線) の他に, 入口（1段目, 破線) と出口 $(30$ 段目，一点鎖線）の層（1段目と 30 段目）の反応率も 併記した。これにより，層全体の反応率分布の時間推移 がわかる.

層内の反応率分布の時間推移は, 反応速度が低い場合 に反応率分布が広くなっている．固定層における反応で は，生成ガスの抑制効果が無い場合は，ガスの入口側か ら順に反応が進行する傾向が強いため, 層の反応率分布 は大きくなり，反応速度が速いほどこれは顕著となる． しかしながら，実際には， $\mathrm{CO}, \mathrm{CO}_{2}$ の反応抑制効果は

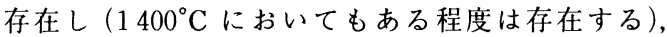
Fig. 14 のような反応速度が大きい場合 $(\Delta)$ に, CO が $40 \%$ にも達しているので, 反応速度の小さい実験より も，逆に層内の反応率分布が小さくなったものと思われ る.この傾向は, 層のようなマクロな領域だけでなく, 一個粒子内のよりミクロの領域にも当てはまり, 反応速 度式の適用にあたって，未反応核的なモデルより，均一 反応モデルの方がより適していることを説明しているも のと思われる.

\section{5. 結}

本研究では，コークスの結晶構造を '黒鉛化した結 晶子とそれらを結ぶ無定形の炭素の混合物 ‘゙あるとし た，単純な見方を通じて製鉄用コークスの速度解析を 行った。これらの結果次のような知見が得られた。

$\mathrm{X}$ 線回折の結果,

（1）Lcは需囲気の影響を受けず，また反忘の有無に かかわらず温度の関数として，成長する.

( 2 ) $L a$ は, Ar 雲囲気中では, 温度の関数として増 加するが，これと比較してガス化実験後には，小さくな る.この結果から，ガス化反応は優先的に $L a$ のみを小 さくする機構で進行するものと考えられた. ガス化実験の結果,

( 3 ) コークスの $\mathrm{CO}_{2}$ によるガス化において，ガス化 速度は $\mathrm{CO}_{2}$ 濃度に比例せず，それが高濃度に存在する 場合はかえって阻害効果がある。

(4)CO には反応抑制効果が認められ，低濃度ほど明 確に現れる。しかし，その効果は，高温になるほど小さ くなる.

（５）コークス中の二種類の反応性の異なる炭素を想定 し, 速度解析を行い, それぞれの炭素に対する速度定数 を求めた。

\section{文献}

1 ) 小林三郎, 大森康男: 鉄と鋼, 63 (1977), p. 1081

2 ) D. A. AderibigBe and J. SZeKely: Ironmaking Steelmaking, 8 (1981), p. 11

3 ) J. V. DUBRaWSKI and $W . W$. GILL: Ironmaking Steelmaking, 11 (1984), p. 7

4 ) 角南好彦, 小川真資: コークス・サーキュラー，26 (1977), p. 262

5 ) 藤田英夫, 聖山光政, 西田清二: コークス・サーキュラー, 29 (1980), p. 218

6 ）石原武彦, 吉野良雄, 土橋幸二: コークス・サーキュラー, 26 (1977), p. 249

7 ) 小嶋鴻次郎, 西 徹, 山口徳二, 仲摩博至: 鉄と鋼, $62(1976)$, p. 570

8 ) 小林和夫: 炭素材料入門 (1972) [炭素材料学会]

9) H. P. Klug and L. E. Alexander: X-ray Diffraction Procedures for Polycrystalline and Amorphous Materials, 2nd ed. (1974) [Wiley]

10) B. P. Richards: J. Appl. Crystallogr., 70 (1972), p. 84

11) P. L. Walker, Jr., F. Rusinko, Jr. and $L$. G. Austin: Advances in Catalysis, XI (1959), p. 133

12) 近藤真一, 石井邦宜, 柏谷悦章, 山下一紀, 中谷庄一: 学振 54 委-No. 1851 (昭和 63 年 2 月)

13) W. E. Ranz: Chem. Eng. Prog., 48 (1952), p. 247

14）北野 康, 市川 勝, 長 哲朗, 井上祥平, 浅田浩二: 炭酸ガスの化学 (1976) [共立出版]

15）小林三郎, 大森康男: 鉄と鋼, 64 (1978), p. 187 